\title{
GÉNERO, ECONOMÍA DEL CUIDADO Y PAGO DEL TRABAJO DOMÉSTICO RURAL EN JILOTEPEC, ESTADO DE MÉXICO
}

\author{
GENDER, CARE ECONOMY AND PAYMENT FOR RURAL DOMESTIC WORK IN JILOTEPEC, \\ ESTADO DE MÉXICO
}

\author{
Pilar Alberti-Manzanares ${ }^{* 1}$, Mirna Zavala-Hernández ${ }^{1}$, Blanca Salcido-Ramos ${ }^{2}$, Natalia Real-Luna ${ }^{3}$
}

\begin{abstract}
${ }^{1}$ Desarrollo Rural. Campus Montecillo, Colegio de Postgraduados. Texcoco, Estado de México. 56230. Carretera Federa México-Texcoco, Km. 36.5. Montecillo, Texcoco (palberti@colpos.mx, mizahe_13@hotmail.com) 2Estrategias para el Desarrollo Agrícola Regional. Campus Puebla, Colegio de Postgraduados. Carretera Federal México-Puebla Km. 125.5 72760. (bsalcido@ colpos.mx) ${ }^{3}$ Campus Córdoba, Colegio de Postgraduados. Carretera Federal Córdoba-Veracruz. CongregaciónManuelLeón,MunicipioAmatlándelosReyes,Veracruz.94946.(nreal@colpos.mx)
\end{abstract}

\section{Resumen $\quad$ Abstract}

El trabajo doméstico y el cuidado de nińas, ancianas y enfermas de las mujeres rurales, crea plusvalía y riqueza económica, desarrolla la economía del cuidado para atender las necesidades de la familia y asegura el equilibrio social en el aspecto político. El valor del trabajo de las amas de casa en México equivale, en millones, a $21 \%$ del Producto Interno Bruto (PIB), por encima del aporte del ramo de la construcción. El tiempo y el esfuerzo invertidos por las mujeres rurales equivale a cuatro jornadas de trabajo al día para atender la casa, el empleo, la familia, y la producción agrícola y pecuaria. Considerando la perspectiva de género, la teoría feminista y la economía del cuidado, se plantea la pregunta: si el trabajo doméstico y de cuidado agrega valor al PIB: ¿por qué no se paga? La investigación realiza una valoración económica del trabajo doméstico y del cuidado en familias rurales del municipio de Jilotepec, Estado de México y plantea el pago monetario del mismo.

Palabras clave: economía feminista, desarrollo rural, mujeres rurales.

\section{INTRODUCCIÓN}

$\mathrm{E}$ 1 tema del artículo surge de la búsqueda de respuestas a la siguiente premisa: si el trabajo doméstico de las mujeres es tan importante para la economía del cuidado y el sistema de producción de los países: ¿por qué no se paga? El objetivo de este trabajo es dimensionar el valor económico del trabajo

* Autor responsable * Author for correspondence.

Recibido: marzo, 2014. Aprobado: junio, 2014.

Publicado como ARTÍCULO en ASyD 11: 379-400. 2014.
Domestic work and caring for girls, elderly and sick women by rural women creates added value and economic wealth; it develops the care economy to address the needs of the family and ensures social equilibrium in the political aspect. The value of housewives' work in México is equivalent, in millions, to $21 \%$ of the Gross Domestic Product (GDP), above the contribution by the construction segment. The time and effort invested by rural women is equivalent to four working days per day to tend to their household, job, family and agricultural and livestock production. Taking into consideration the gender perspective, feminist theory and care economy, the following question is set out: if domestic and care work adds value to the GDP, why is it not paid? This study performs an economic valuation of domestic and care work in rural families of the municipality of Jilotepec, Estado de México, and suggests their monetary payment.

Key words: feminist economy, rural development, rural women.

\section{INTRODUCTION}

$\mathrm{T}$ The subject of the article arises from the search for answers to the following premise: if women's domestic work is so important for the care economy and the production system of countries, why is it not paid? The objective of this study is to measure the economic value of unpaid domestic and care work as part of the productive system of the national economy, based on the rural environment in the municipality of Jilotepec, Estado de México.

The theoretic debate presented integrates the gender perspective and feminist and care economy, 
doméstico y del cuidado no remunerado como parte del sistema productivo de la economía nacional, a partir del ámbito rural en el municipio de Jilotepec, Estado de México.

El debate teórico que se presenta integra la perspectiva de género y la economía feminista y del cuidado, así como los planteamientos sobre el modo de producción doméstico rural, centrado en la consideración de que el hogar no solo es un espacio de cuidados, sino también de consumo junto con la producción de bienes y servicios. Por ello, estudiar las prácticas cotidianas de los hogares rurales para satisfacer las necesidades de sus integrantes, valorando el uso del tiempo y el valor monetario que tienen las actividades realizadas, es muy importante para implementar políticas públicas de bienestar social desde una perspectiva de género. La hipótesis que se plantea en este artículo es que el trabajo doméstico realizado por las mujeres rurales crea plusvalía y riqueza económica, desarrolla la economía del cuidado para atender las necesidades básicas del mantenimiento de la familia y asegura el equilibrio social en el aspecto político. La investigación se realizó en el municipio de Jilotepec, Estado de México con familias rurales y empresas del mercado de servicios durante tres meses en 2012. La principal fuente de empleo para las mujeres son las maquiladoras y el trabajo doméstico remunerado, así como el comercio a pequeña escala. En el municipio existen servicios como lavanderías, tortillerías, tintorerías, cocinas económicas, enfermerías y trabajadoras domésticas. También cuentan con servicio de salud pública y privada, así como con una escuela especial para niños (as) con discapacidad.

La metodología utilizada se sustenta en bases teóricas de la perspectiva de género y la economía feminista. La zona de estudio consideró las siguientes comunidades: Ximojai, Magueysitos, Ejido de Jilotepec, Santiago Oxthoc y Ejido de San Miguel de la Victoria. La unidad de análisis consideró cuatro tipos de familia: 1) familia nuclear, 2) familia extensa, 3) jefatura femenina, y 4) familia con enfermos y discapacitados, considerando un total de 17 mujeres amas de casa. También se consideró a dos funcionarios: uno del Programa 70 y más (que da atención a adultos mayores) y el otro del Programa Oportunidades (que apoya con becas para la educación, alimentación y salud de niños y niñas), así como a 15 empleadas de diversos servicios de la cabecera municipal: lavanderías, tortillerías, cocinas económicas, enfermeras as well as the proposals regarding the rural domestic production mode, centered on the consideration that the household is not only a space for care, but also of consumption and for the production of goods and services. Therefore, studying the daily practices of rural households to satisfy the needs of their members, valuing the use of time and the monetary value that activities carried out have, is very important, in order to implement social welfare public policies from a gender perspective. The hypothesis suggested in this article is that domestic work performed by rural women creates added value and economic wealth, develops the care economy to tend to the basic needs of family maintenance, and guarantees the social equilibrium in the political aspect. The research was carried out for three months in 2012, in the municipality of Jilotepec, Estado de México, with rural families and enterprises in the services market. The main sources of employment for women are assembly plants and paid domestic work, as well as small-scale commerce. In the municipality there are services such as laundries, tortilla shops, dry-cleaning, low-price cafeterias, nurseries, and domestic workers. There are also public and private health services, as well as a special school for children with disabilities.

The methodology used is sustained on theoretical bases from the gender perspective and feminist economy. The study zone considered the following communities: Ximojai, Magueysitos, Ejido de Jilotepec, Santiago Oxthoc and Ejido de San Miguel de la Victoria. The analysis unit considered four types of families: 1) nuclear family, 2) extensive family, 3) feminine head of household, and 4) family with sick and disabled; a total of 17 women housewives were included. Two public officers were also considered: one from the program Programa 70 y más (which assists elder adults), and the other from Programa Oportunidades (which supports with scholarships for education, diet and health of children), as well as 15 women employees from various services in the municipal township: laundries, tortilla shops, low-price cafeterias, nurses and domestic workers. The approaches and methodological tools were: 1) quantitative, by applying 15 socioeconomic questionnaires to housewives from the four types of families considered, and 2) qualitative, by applying: a) participant observation; b) 17 in-depth interviews with housewives, considering: house work, income, 
y trabajadoras domésticas. Los enfoques y las herramientas metodológicas fueron: 1) cuantitativos, con la aplicación de 15 cuestionarios socioeconómicos a las amas de casa de los cuatro tipos de familias consideradas, y 2) cualitativos, aplicando: a) observación participante, b) 17 Entrevistas a profundidad a las amas de casa, considerando: trabajo doméstico, ingresos, uso del tiempo y apoyos del gobierno; c) 2 Entrevista semi-estructurada a los funcionarios encargados de los programa Oportunidades y 70 y más, y d) 15 entrevistas semi-estructuradas a prestadoras de servicios en la cabecera municipal, preguntando sobre tipo de servicio, insumos que emplea, intensidad de las actividades en tiempo y energía, número de empleadas y precio del servicio.

\section{¿Cómo calcular el valor del trabajo doméstico?}

La Cuenta Satélite (2011:3) considera dos elementos: 1) tiempo de trabajo dedicado a las labores domésticas y valoración de la economía del cuidado (de infantes, ancianos y enfermos), 2) información sobre el salario que se aplicaría al valor de ese tiempo. En esta investigación se calculó el valor del trabajo doméstico, multiplicando el tiempo de horas que las amas de casa dedican por el costo real de los precios vigentes en el mercado de servicios de Jilotepec para 2012. El Cuadro 1 muestra la tarifa de precios por servicio.

El número de informantes fue de 32 mujeres y 2 hombres, alcanzando un total de 34 personas.

Las edades de las mujeres entrevistadas se encontraban en el rango siguiente: 65\%, entre 30 y 40 años; $12 \%$, entre 41-50; y $18 \%$, más de 51 ańos. Las informantes reportan una escolaridad de secundaria $(40 \%)$, primaria incompleta $(24 \%)$ y primaria completa $(18 \%)$. Finalmente, $18 \%$ no tiene ninguna instrucción.

La mayoría de las entrevistadas son amas de casa (88 \%); algunas realizan trabajo remunerado y trabajo doméstico (12\%). Cabe señalar que todas se dedican a actividades agrícolas y ganaderas (pues participan en un proyecto productivo de ovinos financiado por la organización campesina UNORCA). Esta investigación fue apoyada por: Red Mujer (Red Movimiento de Unidad Justicia y Enlace Rural, Asociación Civil), UNORCA Estado de México y ANCIAM (Asociación Nacional Campesina e Indígena de Adultos Mayores A.C), las cuales proporcionaron los contactos con las familias entrevistadas. use of time, and government support; c) 2 semistructured interviews with the officers in charge of the programs Oportunidades and 70 y más; and d) 15 semi-structured interviews with service workers in the township, asking about the type of service, inputs she uses, intensity of the activities in terms of time and energy, number of employees and cost of the service.

\section{How can the value of domestic work be calculated?}

The Satellite Account (Cuenta Satélite, 2011:3) considers two elements: 1) work time devoted to domestic labors and valuation of the care economy (of infants, elderly and sick persons), 2) information about the salary that would be applied to the value of that time. In this research, the value of domestic work was calculated by multiplying the time in hours that housewives devote by the real cost of current prices in Jilotepec's service market for 2012. Table 1 shows the price rate per service.

The number of informants was 32 women and 2 men, reaching a total of 34 people.

The age of the women interviewed was in the following age range: $65 \%$, between 30 and 40 years; $12 \%$, between 41 and 50 ; and $18 \%$, more than 51 years. Informants report schooling of secondary (40\%), incomplete primary $(24 \%)$ and complete primary $(18 \%)$. Finally, $18 \%$ lacks any instruction.

Most of the women interviewed are housewives (88\%); some perform paid work and domestic work (12\%). It should be pointed out that all of them are devoted to agricultural and livestock producing activities (because they participate in a sheep productive project financed by the peasant organization UNORCA). This research was

Cuadro 1. Precios de los servicios en Jilotepec, 2012. Table 1. Prices of services in Jilotepec, 2012.

\begin{tabular}{lc}
\hline Servicio & Costo (pesos) \\
\hline Una comida (en cocina económica) & 38 \\
Limpieza de casa (al día) & 150 \\
Lavado de ropa (1 kg) & 12 \\
Enfermera (1 hora) & 13 \\
\hline
\end{tabular}

Fuente: trabajo de campo. Precios de los servicios en Jilotepec, 2012. Source: field work. Prices of services in Jilotepec, 2012. 
Según datos de la Cuenta Satélite 2003-2009, el importe económico del trabajo doméstico no remunerado, contabilizado en millones de pesos, equivale a $21.7 \%$ del PIB; es decir, de aproximadamente $40 \mathrm{mil}$ 144 millones de pesos (Cuenta Satélite, 2011). Cuatro quintas partes de esa riqueza es generada por mujeres y la quinta parte restante proviene de los hombres.

\section{GÉNERO, ECONOMÍA FEMINISTA Y ECONOMÍA DEL CUIDADO}

Las definiciones del concepto Género que se plantean en este artículo son: "Género es una categoría teórica, metodológica y política que analiza la construcción social de la diferencia sexual, cuestiona las relaciones desiguales de poder y propone un cambio hacia la equidad e igualdad" (Alberti, 2011:213); por su parte, Larrañaga (2013:102) define género en términos económicos afirmando que: "el género es una variable estructural de primer orden que afecta a todos los procesos sociales y que organiza el conjunto del sistema socioeconómico, condicionando dinámicas a todos los niveles, tanto a nivel micro como a nivel meso y macro".

La perspectiva de género aporta a la discusión teórica la importancia de las relaciones de poder entre mujeres y hombres, entre hombres, y entre mujeres, en la acción social, política y económica. La aplicación de la perspectiva de género ha revolucionado las ciencias sociales que tenían un enfoque androcéntrico en sus estudios (Alberti, 2011). En este sentido, la Economía y su explicación de las relaciones de mercado con los medios de producción cobran una dimensión más amplia al analizar sus supuestos desde la perspectiva de género y el feminismo.

El papel de las mujeres amas de casa es fundamental para el sistema de producción capitalista porque, además de reproducir biológicamente la mano de obra, convierten el salario del trabajador en fuerza de trabajo. Pero, ¿cómo? Comprando y transformando las cosas que se necesitan para que el trabajador pueda seguir trabajando: "El capital entregado a cambio de fuerza de trabajo es convertido en cosas necesarias, por cuyo consumo los músculos, nervios, huesos y cerebros de los trabajadores existentes se reproducen y se engendran nuevos trabajadores" (Rubin, 1986:99). Para mantener la salud y las fuerzas del trabajador es preciso realizar un trabajo extra para preparar la comida, lavar la ropa, tender las camas, supported by: Red Mujer (Red Movimiento de Unidad Justicia y Enlace Rural, Asociación Civil), UNORCA Estado de México and ANCIAM (Asociación Nacional Campesina e Indigena de Adultos Mayores A.C), which provided the contacts with the families interviewed.

According to data from the Satellite Account 2003-2009, the economic cost of unpaid domestic work, counted in millions of pesos, is equivalent to $21.7 \%$ of the GDP; that is, of approximately 40 thousand 144 million pesos (Cuenta Satélite, 2011). Four fifths of this wealth is generated by women and the other fifth part is from men.

\section{GENDER, FEMINIST ECONOMY AND CARE ECONOMY}

The definitions of the concept of Gender that are set out in this article are: "Gender is a theoretical, methodological and political category that analyzes the social construction of sexual difference, questions unequal relationships of power and proposes a change towards equity and equality" (Alberti, 2011: 213); on the other hand, Larrañaga (2013:102) defines gender in economic terms, stating that: "gender is a structural variable of the first order that affects all the social processes and organizes the whole of the socioeconomic system, conditioning dynamics at every level, both at the micro level and the meso and macro level".

The gender perspective contributes to the theoretical discussion the importance of power relationships between women and men, among men and among women, in social, political and economic action. Applying the gender perspective has revolutionized social sciences which had an androcentric focus in their studies (Alberti, 2011). In this sense, Economy and its explanation of market relations with means of production takes on a broader dimension by analyzing its assumptions from the perspective of gender and feminism.

The role of women housewives is fundamental for the capitalist production system because, in addition to biologically reproducing the workforce, they convert the salary of the worker into workforce. But, how? By purchasing and transforming the things that are needed for the worker to be able to continue working: "The capital delivered in exchange for workforce is converted into necessary things, which, when consumed, reproduce the muscles, nerves, 
cortar la leña, etcétera, trabajo que hacen las mujeres, generando plusvalía. Coincidimos con Gayle Rubin cuando afirma que: "es precisamente ese "elemento histórico y social" lo que determina que una "esposa" es una de las necesidades del trabajador, que el trabajo doméstico lo hacen las mujeres y no los hombres, y que el capitalismo es heredero de una larga tradición en que las mujeres no heredan, (...) no dirigen (...) y no hablan con el dios" (Rubin, 1986: 101).

Nancy Folbre, profesora de economía de la universidad de Massasuchetts, estudia los costos económicos del trabajo doméstico y del cuidado, siendo una de las teóricas más importantes de la economía feminista (Badget y Folbre, 1999).

La economía feminista plantea que el "objetivo último de las actividades económicas debe ser la sostenibilidad de la vida"; es decir, "organizar la producción, la reproducción y los intercambios para que la vida se reproduzca y perdure en las mejores condiciones con justicia e igualdad" (Larrañaga, 2013:98). Este cambio de enfoque se sustenta en dos grandes aportaciones: 1) aborda la construcción social y los principios económicos de la subordinación de las mujeres, ayudando a comprender las formas de desigualdad de género, las jerarquías de las relaciones de poder y la formulación de políticas y acciones, y 2) desafía los principios del análisis económico, haciendo una crítica a la disciplina de la Economía en su conjunto (Benería, 2003). El planteamiento de la economía feminista es equiparar el trabajo familiar doméstico con la producción y el intercambio mercantil como generadores de valor económico (Carrasco, 2003). Se consideró que "la división sexual del trabajo no solo diferencia las tareas que hacen hombres o mujeres, además confiere o quita prestigio a esas tareas y crea desigualdades en las recompensas económicas que se obtienen" (Varela, 2008:209). Las propuestas feministas para el trabajo doméstico fueron variadas en los años setenta; por ejemplo, en España se proponían las siguientes alternativas: 1) una parte de dicho trabajo se adquiriría en el mercado: lavanderías, ropa comprada, alimentos preparados, 2) otra parte de los servicios debería proporcionarlos el sector público: guarderías, centros de salud para personas mayores, asistencia a domicilio para personas enfermas y discapacitadas, y 3) otra parte se compartiría con los varones, puesto que hombres y mujeres dedicarían los mismos esfuerzos y tiempos en el trabajo, fuera y dentro del hogar (Varela, 2008). bones and brains of existing workers and engender new workers" (Rubin, 1986:99). In order to maintain the health and strength of the worker, it is essential to perform extra work to prepare food, wash clothes, make beds, cut wood, etc., work that is performed by women, generating added value. We agree with Gayle Rubin when she states that: "it is precisely this 'historical and social element' that determines that a 'wife' is one of the needs of the worker, that domestic work is performed by women and not men, and that capitalism is inheritor of a long tradition where women do not inherit, (...) do not lead (...) and do not speak to the god" (Rubin, 1986: 101).

Nancy Folbre, professor of economy at the University of Massachusetts, studies the economic costs of domestic work and care work, and she is one of the most important theorists of feminist economy (Badget and Folbre, 1999).

Feminist economy suggests that "the ultimate objective of economic activities must be the sustainability of life"; that is, "organizing the production, the reproduction and the exchanges for life to reproduce and last in the best conditions, with justice and equality" (Larrañaga, 2013:98). This change in focus is sustained in two important contributions: 1) it approaches social construction and the economic principles of women's subordination, helping to understand the forms of gender inequality, the hierarchies of power relations, and the formulation of policies and actions, and 2) it challenges the principles of economic analysis, making a critique of the discipline of Economy as a whole (Benería, 2003). The suggestion of feminist economy is to equate family domestic labor with production and commercial exchange as generators of economic value (Carrasco, 2003). It was considered that "the sexual division of labor not only differentiates the tasks that men or women carry out, but also bestows or takes away prestige from these tasks and creates inequalities in the economic rewards that are obtained" (Varela, 2008:209). The feminist proposals for domestic work were diverse in the 1970s; for example, in Spain the following alternatives were proposed: 1) a part of that kind of work would be acquired in the market: laundries, bought clothes, prepared food, 2) another part of the services should be provided by the public sector: daycares, health centers for the elderly, house assistance for sick and disabled people, and 3) another part would be shared 
La realidad demostró las profundas resistencias masculinas para asumir su responsabilidad en el trabajo doméstico y del cuidado, y la arraigada inercia cultural femenina de seguir educando a las mujeres para desempeñar estas tareas, con el consiguiente resultado de asumir el costo de tiempo (la mujeres tienen menos tiempo libre), energía (aumento de agotamiento, estrés y enfermedades) e ingresos no recibidos. Nancy Folbre considera que el trabajo de cuidados contribuye al bienestar y tendría que considerarse como ingreso. ¿Por qué los hombres no asumen su responsabilidad en el trabajo doméstico? La perspectiva de género respondió la pregunta con los estudios de la masculinidad para explicar la reticencia de los hombres a la igualdad de las mujeres (Bonino, 2003) y la economía feminista mostró la tendencia androcéntrica de la economía tradicional.

El valor del trabajo doméstico está en que provee de relaciones afectivas, de cuidados y de calidad de vida, representando mayor importancia que el trabajo remunerado, y en que es fundamental para que el mercado y el resto de las actividades de la economía y la política funcionen. Por otro lado, la economía feminista cuestionó los modelos de la escuela neoclásica, entre ellos el modelo del homo economicus, a imagen de Robinson Crusoe, el cual había sido definido como un individuo racional que no tiene niñez ni se hace viejo, "no depende de nadie ni se hace responsable más que de sí mismo. El medio no le afecta, participa en la sociedad sin que ésta le influya. Interactúa en un mercado ideal donde los precios son su única forma de comunicación, sin manifestar relaciones emocionales con otras personas. (...) Este homo economicus representa una libertad de actuación que solo puede existir porque hay alguien que realiza las otras actividades" (Varela, 2008:212). ¿Y quién las realiza? Las mujeres. Para que los varones puedan dedicarse únicamente al mercado de trabajo, tener libre disposición de tiempos y espacios, no ocuparse de la casa ni del cuidado de infantes, ancianos y enfermos; por eso es que las mujeres dedican su tiempo y energías a esas actividades, limitando sus propias oportunidades de desarrollo profesional, acceso a puestos de decisión, tiempo libre, salud, libertad de tránsito y vida, en comparación con los varones.

El siglo XXI ha sido denominado el Siglo de los cuidados (Larrańaga, 2013:100). Pensamos que ello se debe al incremento de personas que necesitan cuidado de otras: aumento de la población mundial anciana, with the males, since men and women would devote the same efforts and time for work, outside and inside the household (Varela, 2008).

Reality showed the deep masculine resistances to assuming their responsibility in domestic and care work, and the ingrained cultural feminine inertia of continuing to educate women to fulfill these tasks, with the consequent result of assuming the cost of time (women have less free time), energy (increase in exhaustion, stress and disease), and income not received. Why don't men assume their responsibility in domestic work? The gender perspective responded the question with studies of masculinity to explain the reticence of men towards women equality (Bonino, 2003), and feminist economy showed the androcentric tendency of traditional economy.

The value of domestic work is in that it provides affective relationships, of care and quality of life, representing greater importance than paid work, and in that it is fundamental for the market and the rest of the activities in economy and politics to function. On the other hand, feminist economy questioned the models of the neoclassical school, among them the model of homo economicus, in the image of Robinson Crusoe, which had been defined as a rational individual that does not have a childhood or age: "he does not depend on anyone nor is he responsible for anyone but himself. The environment does not affect him; he participates in society without it influencing him. He interacts in an ideal market where prices are their sole way of communication, without manifesting emotional relationships with other people. (...) This homo economicus represents a freedom of action that can only exist because there is someone who performs the other activities" (Varela, 2008:212). And who performs them? Women. In order for males to be able to devote themselves solely to the labor market, to have free disposition of time and space, not occupying themselves with the household or the care of infants, elders and the sick; that is why women devote their time and energy to those activities, limiting their own opportunities for professional development, access to decision positions, free time, health, and freedom of transit and life, in comparison to the men.

The $21^{\text {st }}$ Century has been called the Century of Care (Larrañaga, 2013:100). We think that this is due to the increase in people who need care from others: an increase in the world elderly 
incremento de enfermos(as) y discapacitados(as) a consecuencia de los conflictos bélicos en varias partes del mundo, y niñas y niños solos que migran a otras regiones, como ocurre en países de América Latina. La economía feminista afirma que el modelo masculino de economía y el uso del tiempo no responden a las necesidades de la vida humana. Por ello se propone que haya un cambio en el paradigma económico y patriarcal: considerar que los cuidados y el bienestar humano "no son un problema ni una obligación de las mujeres, sino un problema y una cuestión social" (Varela, 2008:213); aquí añadiríamos también que es una cuestión política.

En los años ochenta las feministas socialistas anglosajonas propusieron la idea del pago de un salario por el trabajo doméstico y de cuidados como acción de justicia por la plusvalía generada por las amas de casa al país.

El "Informe sobre desarrollo mundial 2012: igualdad de género y desarrollo", elaborado por el Banco Mundial, identificó los siguientes cuatro ámbitos que inciden en las brechas de género: 1) los hogares, donde hay una asignación diferencial de cargas de trabajo y recursos, dejando a las mujeres toda la responsabilidad del trabajo doméstico; 2) las instituciones formales, en las que persisten los prejuicios y la discriminación de género en el marco jurídico y normativo; 3) instituciones informales, en las que persisten normas sociales discriminatorias sobre el trabajo del cuidado y el mercado laboral; 4) los mercados, en los que se dan desventaja para las mujeres en relación con el acceso al mercado laboral y a la propiedad de los activos fijos como la tierra, la vivienda, el agua y los créditos (Ponce, 2012). Proponemos ańadir otro factor: 5) el sector público, que transfiere a los hogares y a las mujeres la carga del trabajo del cuidado, recortando los servicios de guarderías, pensiones por enfermedad, apoyos por incapacidad y discapacidad, entre otros.

\section{VALOR ECONÓMICO DEL TRABAJO DOMÉSTICO Y DE CUIDADOS}

Nancy Folbre plantea la gran similitud que existe entre las responsabilidades de la mujer cuando se dedica a cuidar a su familia y las que tiene en trabajos remunerados, como la enseñanza y la enfermería. Así, el concepto de trabajo del cuidado "destaca el carácter discriminatorio de las normas de género que configuran la división del trabajo entre los sexos tanto population, an increase in sick and disabled people as consequence of armed conflicts in several points of the globe, and lonely children who migrate to other regions, as it occurs in Latin American countries. Feminist economy states that the masculine model of economy and use of time does not respond to the needs of human life. Therefore, it suggests that there should be a change in the economic and patriarchal paradigm: considering that care for humans and their welfare "are not a problem or an obligation of women, but rather a social problem and issue" (Varela, 2008:213); we would also add here that it is a political issue.

In the 1980s, English-speaking socialist feminists suggested the idea of payment of a salary for domestic work and care work as a justice action over the added value generated by the housewives for the country.

The "Report on world development 2012: gender equality and development", elaborated by the World Bank, identified the following four areas that influence gender gaps: 1) households, where there is a differential allotment of loads of work and resources, leaving all the responsibility of domestic work to women; 2) formal institutions, where prejudices and gender discrimination persist within the legal and normative framework; 3) informal institutions, where discriminatory social norms persist regarding care work and the labor market; 4) markets, where there are disadvantages for women in regard to access to the labor market and ownership of fixed assets such as land, housing, water and credits (Ponce, 2012). We suggest adding another factor: 5) the public sector, which transfers to households and women the work load for care, reducing services such as daycares, pensions for the sick, support for incapacity and disability, among others.

\section{ECONOMIC VALUE OF DOMESTIC WORK AND CARE WORK}

Nancy Folbre presents the great similarity there is between responsibilities of the woman when she is devoted to caring for her family and those she has in paid work such as teaching and nursing. Thus, the concept of care "highlights the discriminatory character of the gender norms that configure the division of labor between sexes, both in the family and in the market. Women are supposed to be more devoted to assistance tasks than men, and it is even 
en la familia como en el mercado. A las mujeres se les supone e incluso se les exige una mayor dedicación a las tareas de asistenta que a los hombres" (Badgett y Folbre, 1999:35)

La medición del valor del trabajo doméstico tiene su origen a finales del siglo XIX cuando especialistas en estadística noruegos y daneses incluyeron estimaciones monetarias del trabajo doméstico. También se aplicaron estimaciones en Estados Unidos y en 1921 se concretó que el valor de dicho trabajo alcanzaba entre $26 \%$ y $31 \%$ de la renta nacional (Ruiz, 2000). Estos primeros estudios estaban interesados en conocer la distribución del tiempo de trabajo y ocio de las familias obreras (Saavedra y Santiago, 2007). La Conferencia celebrada en Roma, en 1992, estableció una Metodología del uso del tiempo que permitiera la comparación de los mismos indicadores a nivel internacional. La propuesta de contabilizar e incluir el valor del trabajo doméstico en las cuentas nacionales fue un compromiso de la IV Conferencia Mundial de la $\mathrm{Mu}-$ jer en 1995, que fue firmado por 187 países, incluido México. Gary Becker hace un planteamiento teórico que abona la idea de que el Trabajo No Remunerado en los Hogares (TNRH) es una actividad productiva a pesar de no ser remunerada. En 1995 este economista definió al hogar como agente consumidor y como agente productor de bienes y servicios. "Dichos procesos en el consumo definen actividades de trabajo y orientan decisiones de compra en el mercado, estableciendo patrones de consumo que están estrechamente vinculados con la distribución del tiempo de los individuos: el tiempo destinado al trabajo remunerado en el mercado y el destinado al no remunerado en el hogar (TNRH)" (Cuenta Satélite, 2011:3). Algunos países han presentado una estimación de las cifras que aporta la producción doméstica al PIB: Finlandia, 46.4 \% (2001); Alemania, 29 \% (2001); y España, $27.4 \%$ (2003) (Cuenta Satélite, 20011:4).

En el caso de México, este cálculo se conoce a través de los datos obtenidos en la Cuenta satélite del trabajo no remunerado de los hogares de México (CSTNRHM), "con el propósito de dar a conocer los cálculos económicos de las actividades productivas no remuneradas que se realizan en los hogares en beneficio de sus integrantes, con el fin de dimensionar su aportación al desarrollo de las familias con respecto del total de la economía nacional" (Cuenta Satélite, 2011:2). El Cuadro 2 sobre el PIB en 2009 muestra que el total de trabajo no remunerado (trabajo doméstico más trabajo del demanded of them" (Badgett and Folbre, 1999:35). Measuring the value of domestic work began at the end of the $19^{\text {th }}$ Century, when Norwegian and Danish statistics specialists included monetary estimations of domestic labor. Estimations were also applied in the United States and in 1921 it was concluded that the value of that work reached between $26 \%$ and $31 \%$ of the national income (Ruiz, 2000). These first studies were interested in understanding the distribution of work and leisure time of worker families (Saavedra and Santiago, 2007). The Conference held in Rome, in 1992, established a Methodology of use of time that would allow the comparison of the same indicators at the national level. The proposal of counting and including the value of domestic work in national accounts was a commitment of the $4^{\text {th }}$ World Conference on Women, in 1995 , which was signed by 187 countries, including México. Gary Becker makes a theoretical suggestion that subscribes the idea that Unpaid Work in Households (Trabajo No Remunerado en los Hogares, TNRH) is a productive activity in spite of not being paid. In 1995 this economist defined the household as a consuming agent and as a producing agent of goods and services. "These processes in consumption define work activities and guide purchasing decisions in the market, establishing consumption patterns that are closely related to the distribution of time of individuals: the time destined to paid work in the market and that destined to unpaid work in the household (TNRH)" (Cuenta Satélite, 2011:3). Some countries have presented an estimation of the figures that domestic production contributes to the GDP: Finland, $46.4 \%$ (2001); Germany, $29 \%$ (2001); and Spain, $27.4 \%$ (2003) (Cuenta Satélite, 20011:4).

In the case of México, this calculation is made through the data obtained from the Satellite Account of unpaid work in México's households (CSTNRHM), "with the purpose of divulging the economic calculations of unpaid productive activities that are performed in the households in benefit of their members, and with the goal of measuring their contribution to the development of families with regard to the total of the national economy" (Cuenta Satélite, 2011:2). Table 2, about the GDP in 2009, shows that the total of unpaid work (domestic work plus care work) can represent up to $22.57 \%$ of the GDP, above the manufacturing industry, which is the 
cuidado) asciende a $22.57 \%$ del PIB, por encima de la industria manufacturera, que es la que más aporta, con $16.51 \%$, seguido del comercio, con $14.22 \%$ (Pedrero, 2010)

En México, en 1977 se considera por primera vez la medición del uso del tiempo para contabilizar el one that contributes most, with $16.51 \%$, followed by commerce with $14.22 \%$ (Pedrero, 2010).

In México, in 1977, measuring the use of time to account for domestic work was considered for the first time (Pedrero, 2010). In 1996, 1998, 2002 and 2009 the INEGI carried out surveys that

Cuadro 2. México 2009: producto interno bruto de 2009, a precios de mercado por sectores, en millones de pesos. Table 2. México 2009: gross domestic product in 2009, at market prices by sectors, in millions of pesos.

\begin{tabular}{|c|c|c|}
\hline Sector & Montos & $\begin{array}{c}\text { Proporción respecto } \\
\text { al PIB }\end{array}$ \\
\hline Producto interno bruto total & 11821719.2 & 100.0 \\
\hline Impuestos a los productos, netos & 488974.7 & 4.14 \\
\hline Valor agregado bruto a precios básicos & 11332744.5 & 95.86 \\
\hline Agricultura, ganadería, aprovechamiento forestal, pesca y caza & 483726.4 & 4.09 \\
\hline Minería & 1020097.8 & 8.63 \\
\hline Electricidad, agua y suministro de gas por ductos al consumidor final & 176585.3 & 1.49 \\
\hline Construcción & 796562.0 & 6.74 \\
\hline Industria manufacturera & 1951770.2 & 16.51 \\
\hline Comercio & 1681444.3 & 14.22 \\
\hline Transportes, correos y almacenamiento & 764370.0 & 6.47 \\
\hline Información en medios masivos & 385913.0 & 3.26 \\
\hline Servicios financieros y de seguros & 429836.9 & 3.64 \\
\hline Servicios inmobiliarios y de alquiler de bienes inmuebles e intangibles & 1181110.8 & 9.99 \\
\hline Servicios profesionales, científicos y técnicos & 380155.6 & 3.22 \\
\hline Dirección de corporativos y empresas & 43079.8 & 0.36 \\
\hline Servicios de apoyo a los negocios y manejo de desechos y servicios de remediación & 274755.0 & 2.32 \\
\hline Servicios educativos & 558447.7 & 4.72 \\
\hline Servicios de salud y de asistencia social & 349739.7 & 2.96 \\
\hline Servicios de esparcimiento, culturales y deportivos, y otros servicios recreativos & 44114.4 & 0.37 \\
\hline Servicios de alojamiento temporal y de preparación de alimentos y bebidas & 259159.3 & 2.19 \\
\hline Otros servicios, excepto actividades del Gobierno & 283994.8 & 2.40 \\
\hline Actividades del Gobierno & 484534.4 & 4.10 \\
\hline Servicios de intermediación financiera medidos indirectamente & -216653.0 & -1.83 \\
\hline \multicolumn{3}{|l|}{ Trabajo no remunerado } \\
\hline Trabajo doméstico & 2599438.30 & 21.70 \\
\hline Trabajo voluntario & 14526.33 & 0.12 \\
\hline Trabajo no remunerado producto según scn-93 & 88680.81 & 0.75 \\
\hline Total del trabajo no remunerado & 2702645.45 & 22.57 \\
\hline
\end{tabular}

PIB trimestral; Estadísticas Económicas; ESTADÍSTICAS ECONÓMICAS; Segundo Trimestre 2010, Capítulo 3: PIB Trimestral Nominal. Excepto los últimos cuatro renglones, que son cálculos propios elaborados para este documento. - Trimester GDP; Economic Statistics; Second trimester 2010, Chapter 3: Nominal Trimester GDP. Except in the last four lines, which are calculations by the authors elaborated for this study.

Fuente: Mercedes Pedrero Nieto. Valor económico del trabajo doméstico en México. Aportaciones de mujeres y hombres. Instituto Nacional de las Mujeres, 2010. Source: Mercedes Pedrero Nieto. Valor económico del trabajo doméstico en México. Aportaciones de mujeres y hombres. Instituto Nacional de las Mujeres, 2010. 
trabajo doméstico (Pedrero, 2010). En 1996, 1998, 2002 y 2009 el INEGI realizó encuestas que aportaron información para calcular el valor económico de las actividades domésticas. El Sistema de Cuentas Nacionales (SCN) fue propuesto por la ONU para cuantificar todas las transacciones económicas entre los diferentes agentes del mercado, como producción, distribución, consumo y acumulación (Cuenta Satélite, 2011:5). En este Sistema se recomienda incluir una Cuenta Satélite en la que se especifiquen los servicios domésticos producidos en el hogar para autoconsumo, para ser incluidos en la contabilidad social y que ello permita hacer un adecuado análisis social (Cuenta Satélite, 2011:5).

Considerando los resultados de la Encuesta $\mathrm{Na}$ cional sobre el Uso del Tiempo 2009 (ENUT, 2009), las mujeres dedicaban 42.3 horas en promedio a realizar actividades domésticas y los hombres 15.2, lo cual muestra la permanencia de los roles tradicionales de género (Inmujeres, 2011). Las mujeres trabajadoras remuneradas dedican $79.5 \%$ horas semanales al trabajo doméstico.

El Cuadro 3 asigna pesos al trabajo doméstico. Cabe destacar el dato de proporcionar alimentos, que contabiliza 540872265 pesos en el caso de las mujeres, en comparación con los hombres, con sólo 76225235 pesos.

\section{Trabajo doméstico en la ECONOMÍA CAMPESINA}

¿Qué característica tiene la distribución del trabajo doméstico en el medio rural con respecto a los datos nacionales? La primera característica es que las condiciones de vida en el medio rural son más precarias que en el urbano y, por consiguiente, las mujeres tienen menos apoyo y más dificultades para realizar el trabajo doméstico y de cuidados. La segunda es que las cargas de trabajo en el medio rural son mayores que en el urbano, debido a las condiciones del campo: migración masculina, feminización de la agricultura, y escasa tecnología moderna, como lavadoras, refrigeradores, planchas, cafeteras, aspiradoras, hornos microondas, internet, teléfonos celulares, etcétera. Además, sus viviendas y comunidades no cuentan con servicios de agua entubada, electricidad, caminos, mercados locales y transporte público permanente, cómodo y seguro. Tienen que ir al río a lavar y comprar la comida diariamente, pues no pueden contributed information to estimate the economic value of domestic activities. The National Accounts System (Sistema de Cuentas Nacionales, SCN) was suggested by the UN to quantify all the economic transactions among different agents of the market, such as production, distribution, consumption and accumulation (Cuenta Satélite, 2011:5). In this system it is recommended to include a Satellite Account where the domestic services produced in the household for auto-consumption are specified, to be included in social accounting and for that to allow an adequate social analysis (Cuenta Satélite, 2011:5).

Considering the results from the National Survey on Use of Time 2009 (ENUT, 2009), women devoted 42.3 hours in average to performing domestic activities and men 15.2, which shows the permanence of traditional gender roles (Inmujeres, 2011). Paid working women devote $79.5 \%$ of weekly hours to domestic work.

Table 3 assigns pesos to domestic work. The piece of data of providing food should be highlighted, which accounts for 540872265 pesos in the case of women, compared to men with only 76225235 pesos.

\section{DOMESTIC LABOR IN PEASANT ECONOMY}

What are the characteristics of domestic work distribution in the rural environment with regard to national data? The first characteristic is that the conditions of life in the rural environment are more precarious than in the urban, and therefore, women have less support and more difficulties to carry out domestic and care work. The second is that the loads of work in the rural environment are greater than in the urban, due to conditions in the countryside: masculine migration, feminization of agriculture and scarce modern technology, such as washing machines, refrigerators, irons, coffee machines, vacuums, microwave ovens, internet, mobile phones, etc. In addition, their houses and communities do not have services such as piped water, electricity, roads, local markets and permanent, comfortable and safe public transport. They must go to the river to wash, and buy food daily, because they can't store it and refrigerate it, in addition to walking long distances back and forth due to the lack of transport. 
Cuadro 3. Valor económico bruto del trabajo no remunerado de los hogares por método generalista, tipo de función y sexo. Serie anual de 2003 a 2009.

Table 3. Gross economic value of unpaid work in the households through a generalist method, type of function and sex. Annual series from 2003 to 2009.

\begin{tabular}{|c|c|c|}
\hline \multirow{2}{*}{ Concepto } & 2003 & 2009 \\
\hline & \multicolumn{2}{|c|}{ (Miles de pesos corrientes) } \\
\hline PIB de la economía nacional a precios de mercado & 7555803383 & 11844513755 \\
\hline Total & 1151445258 & 1816849990 \\
\hline Mujeres & 942901904 & 1453545646 \\
\hline Hombres & 208543354 & 363304144 \\
\hline Proporcionar alimentos & 388667724 & 617095519 \\
\hline Mujeres & 341073606 & 540872265 \\
\hline Hombres & 47594118 & 76225235 \\
\hline Proporcionar limpieza y mantenimiento a la vivienda & 298916650 & 424462162 \\
\hline Mujeres & 245699769 & 330746609 \\
\hline Hombres & 63216881 & 93735553 \\
\hline Limpieza de la vivienda & 283364492 & 397126485 \\
\hline Mujeres & 242431760 & 326212893 \\
\hline Hombres & 40932732 & 70913592 \\
\hline Mantenimiento de la vivienda & 15554158 & 27355677 \\
\hline Mujeres & 3268008 & 4533716 \\
\hline Hombres & 12286149 & 22821916 \\
\hline Proporcionar limpieza y cuidado de la ropa y calzado & 173075324 & 240620831 \\
\hline Mujeres & 153991361 & 206282067 \\
\hline Hombres & 19083962 & 34336754 \\
\hline Proporcionar compras y administración del hogar & 125920408 & 177573702 \\
\hline Mujeres & 83119316 & 108994042 \\
\hline Hombres & 42801089 & 68579661 \\
\hline Compras de bienes y servicios & 84922724 & 110172597 \\
\hline Mujeres & 59740072 & 72755764 \\
\hline Hombres & 25182652 & 37416833 \\
\hline Administración del hogar & 40997648 & 57401105 \\
\hline Mujeres & 23379248 & 36238277 \\
\hline Hombres & 17618438 & 31162828 \\
\hline Proporcionar cuidados y apoyo & 126616431 & 283735356 \\
\hline Mujeres & 97923172 & 216050279 \\
\hline Hombres & 30693259 & 67685076 \\
\hline Cuidado general, ayuda y apoyo escolar & 111353180 & 232046266 \\
\hline Mujeres & 85355746 & 176902207 \\
\hline Hombres & 25897431 & 55141059 \\
\hline Cuidados de salud & 17263251 & 51689090 \\
\hline Mujeres & 12567423 & 39148073 \\
\hline Hombres & 4698828 & 12541017 \\
\hline
\end{tabular}


Cuadro 3. Continuación...

Table 3. Continuation...

\begin{tabular}{|c|c|c|}
\hline \multirow{2}{*}{ Concepto } & 2003 & 2009 \\
\hline & \multicolumn{2}{|c|}{ (Miles de pesos corrientes) } \\
\hline Cuidados temporales & 8739726 & 32348899 \\
\hline Mujeres & 6472936 & 25431140 \\
\hline Hombres & 2266789 & $6917 \quad 759$ \\
\hline Cuidados especializados & 8523526 & 19340191 \\
\hline Mujeres & 6094487 & 13716933 \\
\hline Hombres & 2429039 & 5623258 \\
\hline Proporcionar ayuda a otros hogares y trabajo voluntario & 36246722 & 73339420 \\
\hline Mujeres & 21094678 & 50600565 \\
\hline Hombres & 15152044 & 22738855 \\
\hline Ayuda a otros hogares & 20103822 & 50588362 \\
\hline Mujeres & 14104989 & 40456789 \\
\hline Hombres & 5998833 & 10121572 \\
\hline Servicios domésticos no remunerados & 7806769 & 19644805 \\
\hline Mujeres & 5477286 & 15714170 \\
\hline Hombres & 2329482 & 3930435 \\
\hline Cuidado y apoyo a personas & 12297053 & 30946757 \\
\hline Mujeres & 8627703 & 24752620 \\
\hline Hombres & 3669350 & 6191137 \\
\hline \multicolumn{3}{|l|}{ Servicios comunitarios y voluntarios } \\
\hline Organizados & 16124900 & 22751059 \\
\hline Mujeres & 6989689 & 10133776 \\
\hline Hombres & 9153211 & 12617283 \\
\hline
\end{tabular}

Fuente: Cuenta Satélite, 2011:37. Source: Cuenta Satélite, 2011:37.

almacenarla y refrigerarla, además de caminar largas distancias de ida y regreso por falta de transporte.

La antropología y la sociología rural han desarrollado una amplia bibliografía sobre la familia y la economía campesina. La socióloga Christine Delphy (1982) acunó el término de "modo de producción doméstico" para analizar los aspectos socioeconómicos del patriarcado y el capitalismo, afirmando que las desigualdades persistentes entre mujeres y hombres en el mercado de trabajo se sustentan en la explotación del trabajo doméstico de las mujeres. El antropólogo economista Claude Meillassoux (1987) analiza los modos de producción pre-capitalistas, afirmando que en las sociedades primitivas este modo de producción implica la poligamia, para equilibrar demográficamente los grupos pequeños. Alexander V. Chayanov (1981) explicó que la lógica de la familia se basaba en las necesidades de consumo
Anthropology and rural sociology have developed abundant bibliography about family and peasant economy. The sociologist Christine Delphy (1982) coined the term "domestic means of production" to analyze the socioeconomic aspects of patriarchy and capitalism, affirming that the persistent inequalities between men and women in the labor market are sustained on the exploitation of domestic work by women. The economist anthropologist Claude Meillassoux (1987) analyzes the pre-capitalist means of production, stating that this mode of production implied polygamy in primitive societies, to demographically balance small groups. Alexander V. Chayanov (1981) explained that the logic of family was based on the consumption needs for continued subsistence and on exploitation of their workforce; however, he did not take into account women's 
para la subsistencia continuada y en la explotación de su fuerza de trabajo; sin embargo, no consideró el trabajo de las mujeres en su modelo y presentó una unidad doméstica armoniosa y sin conflictos al interior de la misma. Marshall Sahlins (1983) analizó el modo de producción doméstico característico de todas las economías primitivas y campesinas, considerando que "las relaciones económicas dentro de la unidad doméstica se caracterizaban por la colaboración y lo que llamó "generosidad" (Harris, 1986:204). Este autor no dimensionó la importancia de las relaciones de poder y los conflictos presentes que no fomentaban la "generosidad" en absoluto. La crítica a los planteamientos de estos antropólogos es planteada por una socióloga feminista, Christine Delphy, quien "llama la atención sobre la relación de poder entre mujeres y hombres, en lugar de tratar de meter a la fuerza la división sexual entre las categorías preexistentes de la economía política” en sociedades primitivas (Harris, 1986:209). Para los antropólogos clásicos arriba descritos la economía campesina se sustenta en la unidad doméstica en la que las mujeres son controladas e intercambiadas; esta situación es analizada por las antropólogas feministas con el enfoque de género, afirmando que: "la constitución de un ámbito sui generis separado del mundo público o social es también el medio por el cual las mujeres son efectivamente controladas. Cuanto más separadas organizativamente están las unidades domésticas, más confinadas y aisladas en el espacio doméstico están las mujeres y más total es su dependencia de los varones que las representan" (Harris, 1986:218).

En México existen estudios sobre la Unidad Económica Doméstica al estilo Chayanov y la producción capitalista en el medio rural, como el de Víctor Manuel Franco Pellotier (1992) para el caso de las comunidades otomíes del Valle del Mezquital. Investigaciones del Área de Género: Mujer Rural, del Colegio de Postgraduados en Ciencias Agrícolas, muestran la importancia del trabajo doméstico y del cuidado en hogares rurales, resaltando lo siguiente: 1) las hijas desde muy pequeñas se incorporan a labores domésticas; 2) las labores del hogar las realizan siempre las mujeres de la familia, excepto cuando el hombre es viudo o el ama de casa es anciana, en cuyo caso se contrata a otra mujer o se obtiene la ayuda de alguna que sea pariente de la familia. En esto casos el pago se realiza en económico o en especie (Zapata 1994); 3) la jefatura femenina va en aumento en el work in his model and presented a harmonious domestic unit without conflicts. Marshall Sahlins (1983) analyzed the means of domestic production characteristic of all primitive and peasant economies, considering that "economic relations within the domestic unit were characterized by collaboration" and what he called "generosity" (Harris, 1986:204). This author did not measure the importance of relations of power and conflicts present which did not foster "generosity" at all. Criticism of proposals by these anthropologists is presented by a feminist sociologist, Christine Delphy, who "calls attention to the power relationship between men and women, instead of trying to force the sexual division of labor among preexistent categories of political economy" in primitive societies (Harris, 1986:209). For the classical anthropologists described above, peasant economy is sustained on the domestic unit where women are controlled and exchanged; this situation is analyzed by feminist anthropologists with a gender approach, affirming that: "the constitution of a sui generis environment separate from the public or social world is also the means by which women are effectively controlled. The more that domestic units are separate organizationally, the more women are confined and isolated in the domestic space, and the more total is their dependency on the men who represent them" (Harris, 1986:218).

In México, there are studies on the Domestic Economic Unit in the Chayanov style and about capitalist production in the rural environment, such as that by Víctor Manuel Franco Pellotier (1992) for the case of Otomí communities in Valle del Mezquital. Research in the Gender Area: Rural Women, from Colegio de Postgraduados en Ciencias Agricolas, show the importance of domestic work and care work in rural households, highlighting the following: 1) daughters from a very young age are incorporated into domestic labors; 2) household tasks are always performed by women in the family, except when the man is a widower or the housewife is an elder, in which case another woman is hired or help is obtained from a woman who is a relative of the family. In these cases payment is done in money or in-kind (Zapata, 1994); 3) female heads of households are increasing in the rural environment, which implies a higher work load for women, since they take on domestic, care and paid work (Suárez et al., 2011); 4) rural women find paid work performing activities 
medio rural, lo cual implica mayor carga de trabajo para las mujeres, pues asumen el trabajo doméstico, de cuidados y remunerado (Suárez et al., 2011); 4) las mujeres rurales encuentran trabajo asalariado realizando actividades relacionadas con el trabajo doméstico: lavar ropa, venta de comida y empleadas de tiendas (Lázaro y Martínez, 2003).

Cabe resaltar que otro importantísimo aspecto del trabajo doméstico de las mujeres es la preparación de alimentos y la atención de invitados y músicos en fiestas y rituales asociados a las mayordomías (Castañeda, 2004).

\section{LAS MUJERES Y EL TRABAJO DOMÉSTICO Y DE CUIDADOS EN JILOTEPEC}

¿Cómo se aplican los planteamientos teóricos anteriores en Jilotepec? El trabajo doméstico y de cuidados en Jilotepec incluye actividades diarias: cuidado de niños(as) y personas enfermas, preparación de alimentos y limpieza de vivienda; semanales: lavado de ropa, adquisición de mercancías; y mensuales: compra de enseres, trámites y pago de servicios (Zavala, 2013). Además se suman las actividades de producción agrícola y cuidado de animales, como se muestra a continuación:

1) El cuidado de enfermos y discapacitados requiere de mucha dedicación y esfuerzo por parte de las mujeres pues, además de las actividades cotidianas, dedican atención permanente a estas personas. El trabajo aumenta al levantarse más temprano o dormir más tarde para poder cumplir con todo. El siguiente es el testimonio de una madre de familia con un hijo discapacitado:

En las mañanas, por ejemplo, me despierto a la cinco o cinco y media para levantar a los nińos y lo primerito que hago es tender las camas porque si no se pone complicado si las dejo todas destendidas. Después les doy su ropa para que se vistan y mientras ellos se arreglan yo les preparo el desayuno, les doy su leche y les hago unos huevitos o lo que tenga en la casa porque a veces pues no hay mucho. Ya a las siete de la mańana tengo que dejar a los otros dos niños ahí sentaditos para que acaben de comer; su papá nada más se ocupa de que terminen de comer y pues yo me vengo related with domestic work: washing clothes, selling food, and as shop employees (Lázaro and Martínez, 2003).

It should be highlighted that another very important aspect of women's domestic work is food preparation and attending guests and musicians in parties and rituals associated to mayordomias (Castañeda, 2004).

\section{WOMEN AND DOMESTIC AND CARE WORK IN JILOTEPEC}

How are the prior theoretical proposals applied in Jilotepec? Domestic work and care work in Jilotepec includes daily activities: caring for children and sick people, preparing food and cleaning the household; weekly: washing clothes, acquiring goods; and monthly: purchasing essentials, dealing with paperwork and paying services (Zavala, 2013). Also, activities for agricultural production and livestock care are added, as shown next:

1) Caring for the sick and disabled requires much dedication and effort by women, because in addition to daily activities they devote permanent attention to these people. The work increases by getting up earlier or going to sleep later to be able to do everything. The following is the testimony of a mother with a disabled son:

In the mornings, for example, I get up at five or five thirty to get the children up, and the first thing I do is make the beds, because it can get complicated if I leave them for later. Then I give them their clothes to get dressed and while they are doing that I prepare breakfast, I give them their milk and prepare some eggs or whatever I have at home because sometimes there is not much. By seven I have to leave the other two boys sitting there so they can finish eating; their father only looks after them so they finish eating and I come with the child (to the special school). I get here at eight, and I leave him and see if there is someone who can take care of him: if there is no one there, I also have to stay sometimes (Leticia, Ximojai, 2012).

Caring for a person who cannot take care of him/herself entails greater dedication and energy, 
con el niño (a la escuela especial). Aquí llego a las ocho, lo entrego y veo si ya hay alguien que pueda cuidar al niño: si no hay nadie, pues también me quedo a veces (Leticia, Ximojai, 2012).

El cuidado de una persona que no puede valerse por sí misma supone mayor dedicación y energía, además de paciencia, atención, cariño, comprensión, así como aprender a dar terapias, aplicar curas y medicinas de enfermería. En el medio rural existen pocos servicios públicos que atiendan a niños discapacitados, por lo que muchos de ellos viven grandes carencias.

En Jilotepec existe la Escuela de Atención para nińos y niñas con discapacidades, que atiende a las y los infantes desde que son bebés y hasta los 14 años, brindando servicios de rehabilitación y educación básica. Los niños mayores de 12 años llevan un taller laboral donde les enseñan diversas actividades. Las niñas aprenden cocina y costura con el objetivo de que puedan tener un oficio para trabajar más adelante. El personal que atiende a estos menores son maestras especializadas. El servicio es gratuito y solo se da una cooperación de 10 pesos para la comida que se les da a los niños diariamente en la escuela. Cabe señalar que las madres de los menores son las que la preparan.

2) Elaboración de alimentos. Los alimentos se preparan diariamente, por lo menos dos veces al día. Se necesita un trabajo previo: ir a comprar los víveres, preparar la comida, servirla, lavar los trastes y limpiar la cocina nuevamente. El siguiente testimonio refiere la experiencia:

"Tengo que darle de comer a mis hijos; a veces uno de ellos viene a comer, al ratito llega otro y, justo cuando ya estoy recogiendo, aparece el tercero. Uno de ellos trabaja de noche y cuando se levanta para ir a trabajar yo ya tengo todo recogido, pero tengo que servirle y volver a ensuciar; eso es muy pesado y me pongo de nervios. A parte tengo que prepararle el lonche después la cena y por eso siento que nunca acabo; todo el día tengo que estar haciendo de comer y limpiando" (Eugenia, Magueysitos, 2012).

Asimismo, es importante señalar que en el sector rural se hacen tortillas a mano, lo que aumenta in addition to patience, attention, affection, understanding, and also learning how to offer therapies, apply cures and medicine for nursing. In the rural environment there are scare public services that tend to disabled children, which is why many of them experience much lack of attention.

In Jilotepec there is an Attention School for boys and girls with disabilities, which assists children since they are babies and until they are 14 years old, providing services for rehabilitation and basic education. Children older than 12 years old participate in a labor workshop where they are taught various activities. Girls learn cooking and sowing with the objective of having a craft to work with later on. The personnel who attend these minors are specialized teachers. Service is free and a donation of 10 pesos is given for food fed to children daily at the school. It should be pointed out that the mothers of the minors are the ones who prepare it.

2) Food preparation. Food is prepared daily, at least twice a day. Prior work is required: going shopping for supplies, preparing the food, serving it, washing the dishes and cleaning the kitchen, once again. The following testimony describes the experience:

"I have to feed my children; sometimes one of them comes for lunch, then a little while later another one arrives and, right when I begin to clean up, the third appears. One of them works at night and when he rises to leave for work I have already picked everything up, but I have to serve him and get everything dirty again; this is very tiresome and I get anxious. Also, I have to prepare lunch after dinner, and that's why I feel that I never finish; I have to spend all day cooking and cleaning" (Eugenia, Magueysitos, 2012).

Likewise, it is important to mention that in the rural sector tortillas are hand-made, which increases the load of work because it implies going out to search for firewood, preparing the nixtamal, going to the mill to grind the maize, lighting the fire and making the tortillas. Some women have to go to the mountain or other places to search for firewood in sticks or dry branches; they break them and carry them on their back. 
la carga de trabajo porque implica ir a buscar leña, preparar el nixtamal, ir al molino para moler el maíz, prender la leña y hacer las tortillas. Algunas mujeres tienen que ir al monte o a otros lugares a recoger la leña en forma de varas o ramas secas; ellas mismas la quiebran y cargan a la espalda.

3) La limpieza de la vivienda incluye actividades como barrer, sacudir, trapear, limpiar muebles, tender camas y lavar pisos. Estas actividades son realizadas varias veces al día. Por ejemplo, las familias con niños pequeños requieren mayor limpieza por el hecho de que todo el día ensucian.

"En mi hogar nunca tengo un horario... ¿te imaginas? Hay veces que, por decir, a las nueve o diez de la mańana ya tengo todo recogido, pero llega la hora de la comida o de la cena y ya está otra vez todo el reguero. Yo les digo: "es que ustedes no se ponen a pensar que me canso". A mi hijo siempre lo regańo con que ordene sus juguetes, que los ponga en su lugar, pero al final yo termino haciéndolo porque él no me hace caso y dos o tres minutos después otra vez está igual. El trabajo de un hogar es muy pesado y cansado" (Elodia, Ejido de Jilotepec, 2012).

La limpieza de la casa también incluye tener limpias las instalaciones donde se tiene el ganado. En algunas ocasiones los hombres hacen esta labor.

4) Lavado de la ropa: cuando hay agua en las casas, cada ocho días aproximadamente, aprovechan para lavar a mano la ropa acumulada de toda la familia, lo que provocando mucho cansancio y enfermedades con el paso del tiempo.

La escasez del agua en las casas obliga a las mujeres a trasladarse a algún riachuelo u ojo de agua, caminando hasta una hora de ida y otra de regreso con la carga de la ropa mojada, y lavar agachadas en piedras largas acondicionadas como lavadero. Esta posición mantenida por varias horas provoca fuertes dolores de espalda y en los riñones.

"Los días que hay agua potable, que son los jueves, es cuando aprovecho a lavar, lavo mucho, mucho" (Gloria, Santiago Oxthoc, 2012).
3) Cleaning of the household includes activities such as sweeping, dusting, mopping the floor, cleaning furniture, making beds and washing floors. These activities are performed several times per day. For example, families with small children require more cleaning because they make a mess throughout the day.

"In my home I never have a schedule... Can you imagine? There are times that, so to speak, at nine or ten in the morning I have everything already picked up, but then the time for lunch or dinner comes, and the mess is there all over again. I tell them: 'it's just that you do not stop to think that I get tired'. I always scold my son so he will pick up his toys, and put them away, but in the end I wind up doing it because he does not obey me and two or three minutes later everything is a mess again. Housework is very boring and tiring." (Elodia, Ejido de Jilotepec, 2012).

Cleaning the household also includes having the facilities clean where livestock are kept. On some occasions, men perform this labor.

4) Clothes washing: when there is water in the households, every eight days approximately, they take advantage of it to hand-wash the clothes that accumulate from the whole family, causing much exhaustion and diseases, in time.

Water scarcity in the households forces the women to travel to a stream or water hole, walking up to one hour on the way there and another on the way back with the load of wet clothes, and washing by bending down on long stones as a washing place. This position held for several hours causes strong back and kidney aches.

"The days when there is fresh water, which is Thursdays, is when I try to wash, I wash a lot, a whole lot" (Gloria, Santiago Oxthoc, 2012).

5) Acquiring and purchasing supplies: this is done several times per week. This depends on the proximity or distance of the place where they are sold. In the study case all the families live far from 
5) Adquisición y compra de mercancías: se realiza varias veces a la semana. Esto depende de la cercanía o lejanía del lugar donde las vendan. En el caso de estudio todas las familias viven lejos del centro de Jilotepec, por lo que sólo realizan esta actividad los días de tianguis (mercado ambulante semanal). Algunas informantes trabajan también ahí y a la salida de su trabajo compran lo que necesitan. Un problema con los alimentos es que los hogares no cuentan con refrigerador para conservarlos frescos durante varios días, lo cual implica más trabajo para las amas de casa ya que se ven obligadas a comprar menos alimentos, pero con mayor frecuencia, lo cual provoca que tengan que invertir más tiempo en los traslados de su comunidad a Jilotepec.

6) Trámites administrativos y pago de servicios. Cuando las mujeres van a la compra para la alimentación aprovechan para hacer trámites en las oficinas de gobierno, escuelas, tiendas, así como realizar el pago de servicios como vivienda, luz, teléfono, agua, así como dar cooperaciones y hacer depósitos en el banco. Por ejemplo, a los trámites bancarios les tienen que dedicar bastante tiempo porque en Jilotepec no hay muchos bancos y ello provoca que se hagan largas filas. Esta situación obliga a planificar las actividades domésticas, por lo que tienen que levantarse más temprano para realizarlas o hacerlas después de llegar a la casa en la noche. Algunas veces los maridos hacen los pagos de servicios porque les queda cerca del trabajo, pero son las mujeres las que realizan estas actividades la mayoría de las veces, según los testimonios.

7) Cuidado de animales. El trabajo que requiere el cuidado de animales incluye levantarse muy temprano para darles de comer, sacarlos a pastar, meterlos todas las tardes al corral, limpiar el corral, prepararles el agua, y estar al pendiente de las vacunas, los partos y las enfermedades. Posteriormente, al medio día se les tiene que dar agua y comida otra vez; en la noche esto se les alimenta otra vez para después llevarlos a guardar. Algunas de las mujeres entrevistadas son socias de un proyecto productivo de borregas, por lo que tienen que dedicar tiempo a sacarlas a pastorear durante varias horas al día. Otras tienen vacas y becerros
Jilotepec's center, so this activity is only performed on tianguis day (weekly traveling market). Some informants also work there and when they leave their work they purchase what they need. A problem with food is that households do not have refrigerators to keep them fresh for several days, which implies more work for the housewives, since they are forced to buy less food, although more frequently, resulting in them having to invest more time in traveling from their communities to Jilotepec.

6) Administrative paperwork and service payment. When women travel to purchase food, they make the most of it and do paperwork at government offices, schools, shops, as well as pay for services such as housing, electricity, telephone, water, and also make contributions and bank deposits. For example, bank paperwork needs much time because in Jilotepec there are not many banks and this provokes long lines. This situation forces them to plan domestic activities, so they have to get up earlier to perform them or do them after they arrive home at night. Sometimes the husbands make service payments because they are close to work, but it is the women who perform these activities most of the times, according to testimonies.

7) Animal care. The work that animal care requires includes rising very early to feed them, taking them to graze, putting them back in the pen every afternoon, cleaning the pen, preparing their water, and being aware of vaccines, births and diseases. At noon, they have to be given water and food again; at night this is done again to later put them away. Some of the women interviewed are partners in a sheep productive project, so they have to devote time to taking them out to graze for several hours per day. Others own cows and small calves in stables, which implies they must prepare feed and water, give them salt, clean the stables, and milk and tend to calves when they are possibly sick. On occasions this work is shared with the husbands, but they sometimes arrive late from work and do not take on full responsibility.

"Well now, I am tending to the animals and everything... it is heavy (domestic work). 
pequeños en establos, lo que implica preparar la alimentación y el agua, darles sal, limpiar los establos, y ordeñar y atender a los becerros en sus posibles enfermedades. En ocasiones este trabajo se comparte con los maridos, pero éstos a veces llegan tarde del trabajo y no se responsabilizan del todo.

"Pues ahorita sí estoy atendiendo animales y eso... es pesado (trabajo doméstico). Cuando, por ejemplo, está mi esposo, pues él se encarga de ellos, pero como horita no puede pues yo me encargo de animales y de todo lo que es la casa” (Ilda, Ejido de Jilotepec, 2012).

8) Producción en el campo. El cultivo de maíz, frijol y otros productos se realiza durante algunos meses del año. Las mujeres consideran que su trabajo en las tareas de cultivo y recolección es una ayuda al esposo y por ello no reciben ningún salario, mientras que los peones sí cobran por su trabajo. Esta investigación no incluyó el pago de los peones por horas para poder calcular así el costo en pesos que ahorran las mujeres a su familia por realizar esa misma labor.

Los Cuadros 4 y 5 muestran otros aportes de las mujeres a la economía familiar. Estas cifras demuestran el ahorro que generan las mujeres a los hogares y la riqueza que se crea si se incluyera en los porcentajes del PIB del país. Cabe señalar que en esta contabilización del trabajo doméstico rural no se incluyen los costos por el cuidado de animales y por la producción del campo, lo cual aumentaría dichas cifras pues se tomaría en cuenta el pago de un peón por día de trabajo.

\section{Conclusiones}

$\mathrm{Al}$ inicio del artículo se mencionó la premisa de: si el trabajo doméstico de las mujeres es tan importante para la economía del cuidado y el sistema de producción de los países, ¿̨por qué no se paga? Es una pregunta teórica y política de amplias consecuencias porque implica un reto para la economía, la política y las relaciones de género. Se necesita un cambio de los paradigmas económico y patriarcal pues éstos ya no responden a las necesidades de la vida humana, la democracia, la igualdad de género ni los derechos humanos. Tanto en el ámbito urbano como en el rural las mujeres se ocupan del trabajo doméstico y de
When, for example, my husband is here, well, he takes care of them, but since he can't do it now then I have to take care of the animals and everything else in the household" (Ilda, Ejido de Jilotepec, 2012).

8) Production in the field. Cultivating maize, beans and other products is performed during some months of the year. Women consider that their work in cultivation and recollection tasks is a help to their husbands and that's why they do not receive any salary, although the day laborers do charge for their work. This research did not include the use of payments to day laborers per hours to calculate with them the amount in pesos that women help their families save by performing those same tasks.

Tables 4 and 5 show other contributions of women to the family economy. These figures show the savings that women generate in the households and the wealth that is created if they were to be included in the country's GDP percentages. It should be mentioned that in this account of rural domestic work, the costs for animal care and field production are not included, which would increase the figures because the payment for a laborer's work day would have to be included.

\section{Conclusions}

At the beginning of the article, the following premise was mentioned: if women's domestic work is so important for the care economy and the production system of countries, why is it not paid? It is a theoretical and political question of broad consequences because it implies a challenge for economy, politics and gender relationships. There is a need for a change in the economic and patriarchal paradigms since these no longer respond to the needs of human life, democracy, gender equality or human rights. Both in the urban environment and in the rural, women take care of domestic and care work as a result of the cultural and ideological patterns that reproduce the traditional gender roles. From the standpoint of feminist economy, it is suggested that domestic work should be likened to commercial production as a generator of economic value.

We suggest a critical vision of the theory of the homo economicus that, when applied to the rural case, 
Cuadro 4. Valor económico del trabajo doméstico en una familia de cuatro integrantes. Table 4. Economic value of domestic work in a family of four members.

\begin{tabular}{|c|c|c|c|}
\hline Actividad & $\begin{array}{l}\text { Un día } \\
\text { (pesos) }\end{array}$ & $\begin{array}{l}\text { Una semana } \\
\text { (pesos) }\end{array}$ & $\begin{array}{l}\text { Un mes } \\
\text { (pesos) }\end{array}$ \\
\hline Alimentación (tres comidas al día) & 456.00 & 3192.00 & 13680.00 \\
\hline Lavado de ropa (Incluye $5 \mathrm{~kg}$ al día) & 60.00 & 420.00 & 1800.00 \\
\hline Limpieza de casa & 150.00 & 1150.00 & 4500.00 \\
\hline Cuidado de dos menores & 312.00 & 2184.00 & 9360.00 \\
\hline Total & 978.00 & 6946.00 & 29340.00 \\
\hline
\end{tabular}

Fuente: Zavala, 2013:128. • Source: Zavala, 2013:128.

cuidados debido a los patrones culturales e ideológicos que reproducen los roles tradicionales de género. Desde la economía feminista se plantea equiparar el trabajo doméstico con la producción mercantil como generador de valor económico.

Proponemos una visión crítica a la teoría del homo economicus que aplicada al caso rural consideraría a un hombre campesino que no se hace responsable más que de sí mismo. Sin embargo, para que los campesinos se ocupen únicamente de trabajar la tierra, cuidar el ganado, ser pastores, peones, albañiles, trabajadores en las maquilas o mayordomos de las fiestas patronales, que tengan libre disposición de tiempo y espacios, no se ocupen de la casa ni del cuidado de infantes, ancianos y enfermos, es necesario que haya mujeres que dediquen todo su tiempo y energía a estas actividades. Al hacerlo ellas disminuyen sus posibilidades de estudiar, trabajar de forma remunerada, heredar propiedades, transitar libremente, cuidar su salud y disponer de tiempo para el ocio y el descanso.

A través de los datos se ha dimensionado el valor económico del trabajo doméstico y de cuidados en su aporte al PIB de los países y, específicamente, en lo would consider a peasant man who is not responsible for anything other than himself. However, for peasants to occupy themselves only in working the land, caring for the livestock, being herders, workmen, bricklayers, assembly plant workers or mayordomos at patron saint's festivities, and for them to have free regulation of time and space, and not be occupied with the household or care of infants, elders and the sick, it is necessary for there to be women who devote all their time and energy to these activities. By doing this, women decrease their possibilities of studying, having paid work, inheriting properties, free transit, caring for their health and having time for leisure and rest.

Through the data, the economic value of domestic work and of care work has been measured in its contribution to the country's GDP and, specifically, in what refers to the rural environment in México. The hypothesis set out in the research, which stated: "domestic work performed by rural women creates added value and economic wealth, develops the care economy to tend to the basic needs of family maintenance, and ensures the social equilibrium in

Cuadro 5. Valor económico del trabajo doméstico en una familia de cinco integrantes (dos adultos y tres menores, uno de los cuales es discapacitado).

Table 5. Economic value of domestic work in a family of five members (two adults and three minors, one of whom is disabled).

\begin{tabular}{|c|c|c|c|}
\hline Actividad & $\begin{array}{l}\text { Un día } \\
\text { (pesos) }\end{array}$ & $\begin{array}{c}\text { Una semana } \\
\text { (pesos) }\end{array}$ & $\begin{array}{l}\text { Un mes } \\
\text { (pesos) }\end{array}$ \\
\hline Alimentación (tres comidas al día) & 684.00 & 4788.00 & 20520.00 \\
\hline Lavado de ropa & 84.00 & 588.00 & 2520.00 \\
\hline Limpieza de casa & 150.00 & 1050.00 & 4500.00 \\
\hline Cuidado de tres menores & 507.00 & 3549.00 & 15210.00 \\
\hline Total & 1425.00 & 9975.00 & 42750.00 \\
\hline
\end{tabular}

Fuente: Zavala, 2013:127. Source: Zavala, 2013:127. 
que se refiere al medio rural en México. La hipótesis planteada en la investigación que afirmaba: "el trabajo doméstico realizado por las mujeres rurales crea plusvalía y riqueza económica, desarrolla la economía del cuidado para atender las necesidades básicas del mantenimiento de la familia y asegura el equilibrio social en el aspecto político", se confirma al comprobar que, efectivamente, crea plusvalía y riqueza económica a tenor de las cifras de la Cuenta Satélite publicada por el INEGI; desarrolla la economía del cuidado para atender las necesidades básicas del mantenimiento de la familia, como vimos en el caso de las mujeres rurales de Jilotepec que tienen hijos o hijas con alguna discapacidad, y el extraordinario esfuerzo que hacen diariamente para llevarlos al Centro de atención del municipio y encargarse de preparar las comidas de todos ellos. Por último, el trabajo doméstico no remunerado asegura el equilibrio social en el aspecto político, al atender en el hogar las tensiones, depresiones, alcoholismo, violencia, miedo, frustración, enojo, desencanto, cansancio y otros sentimientos humanos generados por la lucha de la vida diaria y contenidos en el hogar, sin que se generen problemas sociales más graves.

Los resultados cuantitativos y cualitativos hallados en la investigación muestran la gran aportación económica que realizan las mujeres al hacer el trabajo diario gratuito. El trabajo doméstico presta servicios fundamentales para la población en alimentación, salud y bienestar emocional, ya que a través de éste las amas de casa aseguran que la vida diaria se desarrolle de manera eficiente para el resto de los integrantes de la familia y así puedan éstos desarrollarse personal y laboralmente. Estos servicios generan ahorro a la economía familiar. Las consecuencias de cuantificar el trabajo doméstico es que ello aumenta las cifras de crecimiento de un país, pero además hace que las mujeres pasen a ser reconocidas como entes productivos, lo que les confiere el derecho de exigir prestaciones y servicios a los gobiernos. Por otro lado, obliga a considerar la relación entre las tareas domésticas, el mercado, el Estado, así como las relaciones familiares y entre géneros, en un nuevo planteamiento de la "economía política de la reproducción doméstica" (Ruiz, 2000).

Además de aportar de esta manera a la economía, las mujeres han salido al espacio público, adaptándose perfectamente a éste, sin dejar de lado las cuestiones domésticas. Sin embargo, los hombres solo participan the political aspect", is confirmed by proving that, in effect, it creates added value and economic wealth in accordance to the figures in the Satellite Account published by INEGI; it develops the care economy to tend to the basic needs of family maintenance, as we saw in the case of rural women in Jilotepec who have children with a disability, and the extraordinary effort they make daily to take them to the municipality's attention center and take on the responsibility of preparing food for all of them. Lastly, unpaid domestic work ensures the social equilibrium in the political aspect, by addressing within the household the tensions, depressions, alcoholism, violence, fear, frustration, anger, disenchantment, fatigue, and other human sentiments generated by the struggle for daily lives, contained in the household, without graver social problems being generated.

The quantitative and qualitative results found in the research show the great economic contribution that women make by performing their daily labor for free. Domestic work provides fundamental services for the population in terms of food, health and emotional wellbeing, since it is through it that housewives guarantee for daily life to take place efficiently for the rest of the family members, so they can develop personally and professionally. These services generate savings for the family economy. The consequences of quantifying domestic work are that this increases the figures of growth in a country, but in addition it helps women to become recognized as productive beings, conferring them the right to demand benefits and services from governments. On the other hand, it forces to consider the relationship between domestic tasks, the market, the State, as well as family relations and between the genders, in a new suggestion of the "political economy of domestic reproduction” (Ruiz, 2000).

In addition to contributing in this manner to the economy, women have moved out to the public space, adapting perfectly to it, without leaving aside domestic issues. However, men only participate in public spaces, without becoming involved in that type of activity. Even when there are symbolic, cultural, economic and political resistances towards valuation and recognition of domestic work and care work, this is explained because in the world and in the country there is still a patriarchal culture, so the roles associating the public with men and the private with women continue to be reproduced. This division of 
en espacios públicos, sin involucrarse en dicho tipo de actividades. Aún existen resistencias simbólicas, culturales, económicas y políticas hacia la valoración y el reconocimiento del trabajo doméstico y de cuidados. Lo anterior se explica debido a que en el mundo y en el país todavía existe la cultura patriarcal, por lo que los roles que asocian lo público a hombres y lo privado a las mujeres se siguen reproduciendo. Esta división del trabajo debe ser sustituida por otra de conciliación de la vida laboral con la familiar y personal.

Concluimos el artículo con una reflexión y una propuesta. La primera se enfoca en que es necesario implementar políticas públicas con perspectiva de género y modificar los patrones culturales e ideológicos tradicionales de género. La segunda consiste en que las mujeres rurales sean reconocidas como ciudadanas con derechos económicos, como son el recibir un salario por la realización de actividades domésticas y de cuidados, así como contar con vacaciones pagadas, seguro de enfermedad y una pensión por jubilación.

\section{Literatura Citada}

Alberti, Pilar. 2011. Los estudios de género y su crítica al androcentrismo en las Ciencias Sociales. In: Rodríguez-Shadow María Jesús y Lilia Campos (Eds) Mujeres: Miradas interdisciplinarias. México, Centro de Estudios de Antropología de la Mujer. pp: 213-236.

Badgett, Lee, y Nacy Folbre. 1999. ¿Quién cuida de los demás? Normas sociosexuales y consecuencias económicas. Revista Internacional del trabajo, vol 118, $\mathrm{n}^{\circ} 3$.

Benería, Lourdes. 2003. La mujer y el género en la economía: un panorama general. In: Villota, Paloma de (ed). Economía y género. Macroeconomía, política fiscal y liberalización. Análisis de su impacto sobre las mujeres. Barcelona, Icaria.

Bonino Méndez, Luis. 2003. Los hombres y la igualdad con las mujeres. In: Lomas, Carlos (comp). ¿'Todos los hombres son iguales? México, Paídós. pp: 105-142.

Carrasco, Cristina. 2003. Mujeres y economía. Nuevas perspectivas para viejos y nuevos problemas. Barcelona, Icaria, $2^{\mathrm{a}}$. Edición.

Castañeda, Patricia. 2004. Mujeres rurales y fiestas en Tlaxcala: la movilización de los recursos femeninos en la organización de comidas rituales. In: Alberti, Pilar (coord) Género, ritual y desarrollo sostenido en comunidades rurales de Tlaxcala. Plaza y Valdés/Colegio de Postgraduados/ CONACYT/Instituto Estatal de la Mujer de Tlaxcala. México. pp: 157-169.

Chayanov, Alexander. 1981. Chayanov y la teoría de la economía campesina. México, Ed. Siglo XXI.

Cuenta Satélite. 2011. Cuenta satélite del trabajo no remunerado de los hogares 2003-2009.México, Instituto Nacional de Estadística y Geografía.

Delphy, Christine. 1982. Por un feminismo materialista. El enemigo principal y otros textos. Barcelona, La Sal Cuadernos Inacabados 2-3. labor should be substituted with one of conciliation of work life with family and personal life.

We conclude the article with a reflection and a proposal. The first is focused on the need to implement public policies with a gender perspective, and to modify the traditional gender cultural and ideological patterns. The second consists in rural women being recognized as citizens with economic rights, such as receiving a salary for performing domestic and care activities, as well as having paid vacation, sickness insurance and a pension for retirement.

- End of the English version -

ENUT (Encuesta Nacional del Uso del Tiempo). 2009. Tabulados Básicos Definitivos. México. Instituto Nacional de Estadística y Geografía.

Franco Pellotier, Víctor Manuel. 1992. Grupo Doméstico y reproducción social. Parentesco, economía e ideología en una comunidad otomí del Valle del Mezquital. México, Centro de Investigaciones y Estudios Superiores en Antropología Social (CIESAS).

Harris, Olivia. 1986. La unidad doméstica como una unidad natural. In: Nueva Antropología, Vol VIII Nº 30 México, pg. 199-222.

Inmujeres (Instituto Nacional de las Mujeres). 2011. Trabajo doméstico no remunerado equivale a $21.7 \%$ del PIB. Comunicado de prensa 61, México, Instituto Nacional de las Mujeres. D.F. www.inmujeres.gob.mx/sala-de-prensa. Consultado 28 julio 2011.

Larrañaga, Mertxe. 2013. Algunas claves de la economía feminista. In: Otero, Tereixa; Raquel Platero, Lorena Klemen. Alternativas feministas ante la crisis. Mundubat. San Sebastián. pp: 97-112.

Lázaro, Rosa, y Beatriz Martínez. 2003. Mujeres jefas de hogar y relaciones de género en los municipios de Doctor Nora y Victoria, Guanajuato. In: Martínez, Beatriz y Emma Zapata (coord) Espacios múltiples, horas interminables: quehaceres de mujeres. Ed. Colección Estudios. Instituto de la Mujer Guanajuatense. México. pp: 23-86.

Meillassoux, Claude. 1987. Mujeres, graneros y capitales. México, Ed. Siglo XXI.

Pedrero Nieto, Mercedes. 2010. Valor económico del trabajo doméstico en México. Aportaciones de mujeres y hombres, 2009.México, Instituto Nacional de las Mujeres.

Ponce Meléndez, Carmen. 2012. El trabajo doméstico no remunerado equivale al $21.7 \%$ del PIB. México, comunicado de prensa 61. www.inmujeres.gob.mx/sala de prensa 21 julio (consultado 28 julio 2012).

Rubin, Gayle. 1986. El tráfico de mujeres: notas sobre la economía política del sexo. In: México, Nueva Antropología, Vol VIII, No 30. pp: 95-145.

Ruíz, Miriam. 2000. El trabajo doméstico arrojaría el doble de ganancias al PIB que el sector de la construcción. México, Red de Noticias CIMAC, 19 julio. 
Saavedra, N., y R. de Santiago. 2007. La clasificación de actividades sobre el uso del tiempo. Cuadernos de Trabajo I. México, Fondo de Desarrollo de las Naciones Unidad para la Mujer/ Instituto Nacional de Estadística y Geografía.

Sahlins, Marshall. 1983. Economía de la edad de piedra. Barcelona, Ed. Aka.

Suárez San Román, Blanca, Emma Zapata, Rosario Ayala, Naima Cárcamo, y Josefina Manjarrez. 2011. ¿...Y las mujeres rurales? Avances y desafíos en las políticas públicas. México. Instituto Nacional de Desarrollo Social/GIMTRAP A.C.
Varela, Nuria, 2008. Feminismo para principiantes, Barcelona, Ediciones B. Grupo Zeta.

Zavala Hernández, Mirna F. 2013. Valor del trabajo doméstico no remunerado en la zona rural de Jilotepec, Estado de México. Análisis de Género. Tesis de Maestría en Desarrollo Rural. Colegio de Postgraduados en Ciencias Agrícolas. Texcoco.

Zapata, Emma, Marta Mercado, y Blanca López Arellano. 1994. Mujeres rurales ante el nuevo milenio. Colegio de Postgraduados en Ciencias Agrícolas. México. 